"The problem is never the faith, it is the faithful and how we behave towards each other"

Kofi Annan

\title{
Europe and Islam: Internalizing the External 'Threat'
}

\section{Naozad Hodiwala}

\begin{abstract}
This article will first characterize the nature of the Islamic 'threat' facing modern day Europe, by arguing that such 'threats' are fed by the forces of internalization. By specifically focusing on case studies found in Jytte Klausen's "The Islamic Challenge: Politics and Religion in Western Europe", this article will take as its departure point the basis that "Europeans tend to ignore the fact that their established norms and policies are not necessarily secular, but reflects long-standing practices that were instituted in order to appease national churches". Three facets of European society will be examined; national laws, media coverage, and politicians and their actions.
\end{abstract}




\section{Introduction}

Clichés abounded in Tony Blair's March 5 $5^{\text {th }}, 2004$ speech to his Sedgefield constituents; Blair spoke of a new "global threat" facing Europe; one that was not only "real and existential...unlike anything the world has faced before" but "needed to be won...whatever the political cost". In an attempt to justify military action in Iraq and join an 'Alliance of the Willing' in a 'War against Terror', Blair warned "everything about our world is changing" and as such traditional 'security' words like terrorists, threat, tyrannical, cruel, nuclear, and war came to be freely used in the same breath as religion, migrants (specifically Islamic immigrants) and countries such as Pakistan and Malaysia suggesting that war, security and migration were all somehow synonymous.

Blair's remarks reflect a growing anxiety amongst Europeans and their politicians over a perceived incompatibility between migrants, the European continent and its way of life. Whilst the rest of the world looks outward, fearing the actions of transnational terrorist networks such as Al Qaeda, Hizbollah and the PLO, Europe is facing a new supposed threat characterized by a different language, colour of skin, and culture. In 2002, Jean-Marie Le Pen, leader of the French Far-Right party the Front Nationale (FN), called migration the "biggest problem facing France, Europe, and probably the world", warning unless action was taken "we risked being submerged" (BBC, 2007). Such hysteria seems to have found general support among the domestic electorate; for example, a 2005 UK Mori poll found that migration was the second most important issue behind only foreign affairs/defence and international terrorism (Van Selm, 2005). 
The 'War against Terror' (and geopolitics to a great extent one can argue) has been transformed itself into, amongst other things, a bipolar religious fracture between the West and Islam. Furthermore, not only did Islamic migrants pose a threat to Europe but seemingly to its future as well; Blair's remarks at the time were echoed by French presidential hopeful, Nicholas Sarkozy, who on October 7, 2006, labelled Turkey's future entry into the European Union as the "end of political Europe" on the basis that "it would worsen the 'problem' of Muslim integration in the continent" (Le Figaro, 7 October 2006). Politicians were not the only ones speaking in such apocalyptic terms; journalists and academics are equally guilty. Timothy Savage, in Europe and Islam: Crescent Waxing, Cultures Clashing, remarks that given the current dynamics -he is referring here to the European-Islamic nexus and the consequent Muslim factor - Europe faces additional complications for achieving its goal of an ever closer union and warns that if accommodation is not reached, Europe's increasingly "ghettoized but rapidly growing Muslim minority" would result in national retrenchment and civil conflict forcing a "Fortress of Europe" and an inevitable "decline on the international stage" (Savage, 2004: 26). Preying upon this frenzy, the Italian journalist Oriana Fallaci's 2004 book, The Force of Reason has sold more than a million copies. Fallaci passionately argues that "Europe is no longer Europe, but rather it is 'Eurabia', a colony of Islam, where the Islamic invasion does not proceed only in a physical sense but also in a mental and cultural sense; servility to the invaders has poisoned democracy, with obvious consequences for the freedom of thought and for the concept itself of liberty" (Walker, 2006: 1).

The inclusion of the movement of persons within the security debate has drawn much deserved attention to the changing complexity of European society; it has not only complicated the migration debate facing Europe and forced migration to the forefront of state 
security discourse but has emerged at a time when the traditional 'state-centred' concept has been replaced by one that surrounds the individual - human security. Inaccurate perceptions fed by a biased Western media have been embraced by a number of European political parties, leading to the introduction of 'knee-jerk' national legislation that inevitably reflects the current external political and power conflicts (such as the 9/11 attacks, the Israeli-Palestinian conflict and the invasions of Afghanistan and Iraq). Most of the research thus far has dealt directly with the effects European citizenship laws, employment discrimination, and religious/cultural differences have had on the integration of Muslim migrants in Europe, for example, Jytte Klaussen's Politics and Religion in Western Europe, Tariq Ramadan's To be a European Muslim, John Esposito's The Islamic Threat: Myth or Reality and Seyla Benhabib's Claims of Culture. However, this paper presents an alternative approach that examines the role the media, irresponsible leadership, and laws play in constructing a false sense of fear and threat in the hope of, both, illustrating and drawing attention to European examples where Islamic migrants and long term residents are viewed and treated as state threats by the media, political leaders, and domestic law, and thus reasserting half-truths and negative stereotypes. Sections II and III outline the attitude and common perception with which European media, political leaders/foreign ministers, and national laws are fueling the prejudices and insecurities of a changing populous struggling to come to terms with differences in language, culture, customs, and religion. Instead of solving the issue of migration, state laws, political language, and the media's often one dimensional portrayal of the Islamic community appears to be worsening relations between Europe's diverse communities. Based on the 2006 UN Report titled Alliance of Civilizations, section IV concludes by outlining some of the greater implications such a trend will have on EU policy initiatives and the possible changes necessary if the issue is to 
improve. If the state can succeed in enacting xenophobic laws, such as the UK's AntiTerrorism Crime and Security Act (ATCSA) or the German system of racial profiling that, according to Fekete in Anti-Muslim Racism and the European Security State, equates migrants to criminals, then it should come as little surprise that the average citizen persistently describes feeling 'threatened' by the level of migration entering their country. I argue, Europeans 'internalize' what they see and hear and project this onto their neighbouring Pakistani taxi-driver or Algerian hijab wearing school teacher. Such a project can prove invaluable given the words of ex-British Foreign Office diplomat, Patrick Bannerman:

How non-Muslims think of Islam conditions the manner in which they deal with Muslims, which in turn conditions how Muslims think of and deal with non-Muslims (1988: 219).

\section{Submerging Europe?}

Despite Samuel Huntington's warning of a 'clash of civilizations' the Muslim world is not as alien to Europe as one might think. After all, Judeo-Christian civilization was shaped by the Mediterranean Sea, whose waters providing a common communication system; "North Africa was a Roman province, Egypt's Queen Cleopatra was a Greek, Southern Spain was a Muslim province for seven centuries, and the Balkans were dominated by Islam until the $19^{\text {th }}$ century" (Walker, 2006: 2). The Crusades were more than a war between two monotheistic belief systems - they were a cultural exchange from which the European Christians emerged enriched by 'Arabic' numerals and medicine. Furthermore, during the 1950s and 1960s during the post-war rebuilding phase, open policies inviting Turkish and Algerian 'guest workers' into Germany and France were actively pursued. These 'newcomers' were, as Mantouvalou describes, a source of "cheap and flexible" labour who were seen as indispensable, if the German and French economies hoped to rebound and meet the needs of its burgeoning 
economy (2005: 120). Germany's guest worker program was based on a series of recruitment agreements with Italy, Spain, Greece, Turkey, Morocco, Portugal, Tunisia, and Yugoslavia. Similarly, Italians from the south moved to Switzerland, and Portuguese and Spaniards to France. France received mostly African migration, while transoceanic migration from the West Indies, India and Pakistan was directed at Great Britain. Successive economic recessions of the 1970s, along with increased social tensions and the first oil price shock, led to the abrupt abandonment of the Franco-German 'promotional' immigration policy and the adoption of more-control oriented approaches. Even though restrictive immigration policies had temporarily placed a moratorium on foreigners entering into their countries, the number of migrants "continued to rise due to the higher fertility rates and the admission of refugees and asylum seekers" (Zimmerman, 1995: 47).

Two pertinent observations can be made from this brief account; first, contrary to the arguments of Robert Leiken; Bernard Lewis, and Jean-Marie Le Pen, migration is not a new phenomenon that has crept up on Europe. Migration has systematically maintained its presence through out the post-War era characterized by periods of elevation or decline. Second, and perhaps more surprisingly, is that a great deal of migrants and asylum seekers between the 1950s and 1990s were from within Europe; that is, Germany attracted Turks and people from former Yugoslavia, France received Africans and the United Kingdom attracted mainly migrants from EU member states.

Interestingly enough it is likely that future migration streams will float along the same lines; Eastern Europeans to Germany, Austria and the Benelux countries; Turks to Germany and the Netherlands; Africans to France, Italy and Spain; and Asians to the United Kingdom (Zimmerman, 1995:52). Papadimitriou reaffirms this in his paper titled, "Think Again: 
Migration" in which he disputes that immigration is 'out of control', labelling it a myth. Papadimitriou points out that not only do 'classic immigration' countries like the US, Canada, and Australia "presently receive less immigration than they had at the beginning of the twentieth century...but, 'non-typical immigration countries' like France, Germany, and Japan have also experienced significant immigration movements in the past" (2005: 122).

\section{An Alliance of Civilizations}

In a recent poll conducted by the international polling firm GlobeScan together with the University of Maryland's Program on International Policy Attitudes (PIPA), 27 countries, surveyed between November 2006 and January 2007 revealed that most people around the world "clearly reject the idea that Islam and the West are caught in an inevitable clash of civilizations": the tensions between Islam and the West arises "from conflicts over political power and interests and not from differences in religion and culture"(Program on International Policy Attitudes 2007). Perhaps the strongest finding is that most people around the world clearly rejected the idea of an inevitable 'clash of civilisations' but rather, a majority of those surveyed, see the problem as the result of intolerance by minorities on both sides and not from either culture as a whole. Finally, the idea that violent conflict is inevitable between Islam and the West is rejected by Muslims, non-Muslims and Westerners alike - 56 percent of respondents believed that 'common ground can be found'. Respondents were asked not only their religious affiliations but also to what extent their religion played a role in how they approached political and social issues. The analysis showed no consistent pattern; in a few countries, those who are more religious are somewhat more likely to say that conflict is inevitable (Turkey and Hungary), but in a larger number of countries this category those who 
placed themselves in this category were slightly more likely to say that it is possible to find common ground (Argentina, Chile, Nigeria, Poland). The 2006 Alliance of Civilizations Report released by the United Nations reiterates these findings.

It is said the Alliance of Civilizations was born on a flight from Spain to New York, hours before Spanish Prime Minister Jose Luis Rodriguez Zapatero was set to address the $59^{\text {th }}$ General Assembly (September 21, 2004) at the United Nations. Aimed at "bridging the growing cultural and political gap" (Barrenada, 2006: 100), the Alliance signified a shift in Spanish foreign policy. After successfully removing the Conservatives from power (who had held power for eight years), the Social Democrats were adamant on reversing some of the previous governments policies. The new government sought to follow a path of multilateralism that moved away from the United States and boosted not only its image in the East but its soft power as well. Considered a "clear, timely, and necessary initiative" the idea was embraced by a variety of countries and regional authorities - the EuroMed Parliamentary Assembly, Organization of the Islamic Conference and the League of Arab States, Brazil, Argentina, Costa Rica, Iran, Italy, Egypt, Indonesia, and Tunisia to name a few (Barrenada, 2006:100).

The report covers everything from possible causes of the West-Islam divide to Youth exchange programmes (like Eramus Mundus) as suggestions for fostering greater cultural understanding. However, of utmost pertinence are the observations made by the 16 member high-level group, encompassed of individuals with a cultural and/or geographic background, who unequivocally point to the "exclusivist ideologies, adversarial perceptions, cultural arrogance, and media stereotypes" as the root cause behind poor relations between Western and Muslim societies (Alliance of Civilizations, 2006). 
Furthermore, the report points towards the continued occupation by Israel of Palestine and other Arab territories, as well as the unresolved status of Jerusalem, as the "primary causes of resentment and anger" (Alliance of Civilizations, 2006). Their reference to external events does not end there. Mention is made of the Soviet occupation of Afghanistan (from 1979-1989) and the subsequent western support for the Mujahadeen, the 9/11 attacks and the war in Iraq as equally destructive. These attacks encourage bias in media projections that are then exploited by politicians who in turn implement strict anti-terrorism and border security regulations that inevitably serve to acerbate negative perceptions.

\section{European Media}

The media is often referred to as a "bridge between cultures and societies" serving to educate and inform their viewers and readers (Alliance of Civilizations Report, 2006: 6.24). Globalization and improved technology permit both the West and Muslim populations' access to a broad range of mediums that cover a vast array of issues and events. However, since September 11, 2001, "an appreciably more nationalistic and anti-Muslim tone has become evident in news and commentary" (Alliance of Civilizations Report, 2006: 6.24). News stories that give time and space only to the most extreme of religious voices in the Muslim and Western world propagate a skewed perspective of Islam, and its followers by falsely casting the Euro-Islam migration debate in narrow bipolar terms - Western secularists against Eastern religious activists. Similarly, media focusing on radicalism and equating Islam with extremism that threatens the West serves to portray Muslims as instigators and protagonists. That is, by creating "a moral and actual panic by presenting the country as under attack", the media legitimizes the myth that Europe is being overrun by 'Jihadists' here to not only steal European jobs and social security but also terrorize the local communities they live in and 
spread fundamentalist thought. The European public sees Osama bin Laden and his fellow Al Qaeda members on TV and believes them to be the ambassadors of Islam. Terms like 'Islamic terrorist', 'Muslim fundamentalist', 'Sunni bombers', and 'Arab killer', have increasingly entered popular culture, print, and broadcast media.

The tales of terror and oppression by terrorists projected by European media to Europeans at large have had a role in Islam's negative portrayal. Although the manifestation of jihadists has great audience appeal and allows "for media twists and dramatic flourish that bode well for the ratings" (Abdullah, 2007), such pessimistic depictions help reassert halftruths and falsehoods. Every time we see an article on the Muslim-European community it is bizarrely accompanied by a praying man wearing traditional Muslim dress, with his hands before him, as if to suggest that Muslims do not wear jeans and t-shirts!

The anti-Islamic cartoons published in a leading Danish newspaper, Jyllands-Posten (JP), under the guise of free speech, were similarly designed to offend and provoke Danish Muslims. Fleming Rose, the cultural editor for the JP, published the 12 anti-Islamic cartoons (depicting the Prophet Mohammed in a variety of offensive, comical, and disrespectful ways) hiding behind the virtues of free-speech (see figure 1). When asked if the editors truly wished to antagonize Muslims, Rose's response was that he supported freedom of speech and was against self-censorship and as such could not be held responsible for the ramifications. When the interviewer persisted and inquired if he regretted his decision knowing the uproar it caused, Rose remarked, "[t]hat is a hypothetical question. I would say that I do not regret having commissioned those cartoons and I think asking me that question is like asking a rape victim if she regrets wearing a short skirt Friday night to the discotheque" (Bollyn, 3 February 2006). Furthermore, in support of the Danish editor, the comics were soon picked up by seven 
other newspapers across Europe. France, Germany, Italy, the Netherlands, Spain and Switzerland who simultaneously reprinted the cartoons on February $1^{\text {st }}$ suggesting a coordinated attempt at defending the rights of free-speech but seemingly quite willing to ignore any responsibility of journalistic integrity or the impact that such inaccurate depictions would have on how local Muslims migrants would be perceived. As Heiko Henkel noted,

to demand toleration from the targets of a racist slur coupled with blunt religious insult, and to brand those who refuse to be silent as fundamentalist - thus denying them any legitimate place within European society - is more than simply inconsiderate... it performs a double delegitimation of religious Muslims on the grounds of being both foreign and intolerant (Henkel, 2006:3).

\section{Political Leadership}

As American bombers were driving Afghanistan's Taliban rulers from power in 2001, a reporter asked then Defence Secretary, Donald Rumsfeld, if the campaign was perversely boosting support for the Islamists. His reply was that it was "very difficult to go down and do a Gallup poll" so he was "not inclined to chase that rabbit" (The Economist, March 10, 2007: 56-58). Since then a variety of research pundits have tried to prove Mr. Rumsfeld wrong and although the aforementioned 2007 survey does not go that far, it does place the source of tensions between Islam and the West squarely on the shoulders of conflicts that occur over power struggles within political circles. Although there are a variety of dimensions one can look at to examine the role politics plays in shaping the migration debate for Europeans, this article focuses exclusively on state leadership and speeches made by government representatives to their electorate.

Often the vocabulary, diction and tone used by Prime Ministers, Presidents, foreign and interior ministers in their speeches have an "inflammatory and destructive" effect when "disseminated by the media" spreading hatred and feeding Islamophobia, xenophobia, and 
anti-Semitism (Alliance of Civilizations 2006: 5.16). In the UK, locals are told that practices such as forced marriage and genital mutilation have persisted because of an over-emphasis on "cultural difference" and "moral relativism" (Khundnani, 2002); in France, according to François Fillon (Minister of Social Affairs, 2002-2004) a sense of 'communautarisme' is to blame for the loss of French values and history (Le Monde, 16 September 2003); in the Netherlands, Prime Minister Balkenende told the nation that his country "does not constitute an aggregation of different cultures" pointing to street gangs that consist entirely of foreign youth to prove his point that Dutch society is failing; and finally in Spain where in 2002 then Prime Minister Aznar blamed multiculturalism as "one of the great threats facing Europe: it is precisely what splits society" (Fekete, 2002a; 2002b). In each case multiculturalism and immigrants are treated as a hazardous entity threatening a country's homogenous identity, history, and culture. It comes as no surprise then that $58 \%$ of the British population, in 2005 , wanted to see tougher immigration controls (Van Selm, 2005). Add on the relentless focus paid by politicians to the 'fight' against illegal immigration, with constant reference to the large numbers of them that cross state borders, has left the impression that the state is defenceless, weak, and in disarray, leading to an increase in the popularity for right wing political parties such as France's FN, Germany's NPD, and the Dutch List Pim Fortuyn, whose stated mandate is strict border management, tighter security, and restrictive measures towards migrants.

Although the issue of migration is most often dealt with at the national level, the European Union and its Members of Parliament (MEP's) have shown an increased interest in protecting its borders from illegal entry establishing EURODAC ${ }^{1}$ and FRONTEX ${ }^{2}$;

\footnotetext{
${ }^{1}$ An EU-wide finger printing database facilitating the identification of repeat asylum seekers and aliens; the act of finger printing is commonly related to criminals and criminal activity.
} 
"regarding the fight against illegal immigration and management of borders, MEPs "recognise the need to adopt an equitable EU return directive" and stress that "mass regularisation of illegal immigrants is not a solution in the long term". Finally, members urge Member States to step up cooperation with FRONTEX" (EP Press Release, 2006).

By repeatedly referring to certain external spectacular events, they are producing a "false consciousness of impeding danger" linking the immigrant population to "perceptions of nonspecific and diffuse, but nonetheless serious threats" (Fekete, 2004:7). Framing the issue of migration with language that is most often associated with traditional understandings of security discourse ('old security'), politicians and European leadership are enhancing their reach and extending, quite willingly, the arm of the law into daily European life apparently unphased by the subtle but progressively greater encroachments on immigrant civil liberties and fundamental human rights. Examples of such laws will be examined below.

\section{Acts and Laws}

In the immediate aftermath of September 11, the EU reacted by passing the EU 2001 Common Positions and Framework Decision on combating terrorism; terrorism no longer exclusively referred to extreme acts of violence committed to further a political cause. According to the EU, any action designed to "seriously damage a country or international organization... [that] unduly compelled" a government to act in a particular way could be considered an act of terror (Fekete, 2004: 5). Furthermore "subsequent inclusion under the definition of all those who gave terrorism 'any form of support, active or passive" were also considered terrorists (Fekete, 2004: 5). Member states soon began to incorporate the EU decision into domestic law leading some states to pass state of emergency legislation and new anti-terrorist laws. As Fekete points out, "in effect, EU governments have used the opportunity that September 11 afforded to expand the definition of terrorism and spread the tentacles of

\footnotetext{
${ }^{2}$ An independent body created to coordinate the operational cooperation between Member states in the field of border security and management - the activities are intelligence driven.
} 
the security state in previously unthinkable ways" (Fekete, 2004: 5). One such example was the 2001 UK Anti-Terrorism Crime and Security Act (ATCSA), which legalized the internment of foreign nationals for a period of two years without trial.

The Danish Police Intelligence Service (PET) and the Norwegian Police Security Service (PST) place a duty upon universities to collaborate with security services' intelligence-gathering procedures on the grounds that foreign students my attempt to register at universities to access information or use equipment that might be used to produce weapons of mass destruction. The German system of profiling of foreign nationals from Islamic states, which started with universities but has since been extended to private businesses, is unprecedented in scale. By April 2002, the federal states' criminal investigation department had assembled 6 million personal records and singled out well over 20,000 potential suspects, even though there was no concrete evidence against them (Fekete 2004: 8). To qualify for inclusion on this list, suspects have to be of (presumed) Islamic religious affiliation, 'from an Islamic state', aged 18 to 24 and not previously have come to the notice of the criminal investigation department. Of course, who is more suspect than a young Muslim man without a criminal record? An interview conducted with a female Muslim in the United Kingdom on the role her government has played in fuelling the discrimination and social marginalization notes that the actions by the state, however unintended, are viewed by Muslims as targeted specifically at them:

all the legislation that is coming out, like the immigration stuff and the citizenship stuff, it's all targeted at Muslims. I'm sorry to say it but it is. No one goes on about how the Australians will have to take citizenship tests. ...I think a lot of the Islamophobia arises from the fact that the Muslims are perceived to be 'a problem' in terms of public disorder and socio-economics, and not doing very well at school and are 'a burden on the state'(EUMC Report 2006a:29). 
By linking immigration to terrorism and Islamic fundamentalism, in the face of external instability and conflict, such laws are 'old security' attempts to deal with 'new security' issues. Laws such as the ATCSA unjustifiably portray the relationship between the state and immigrants as adversarial; seen as a security threat immigrants are not granted the same rights and freedoms that locals enjoy. This negative portrayal is internalized by the public who see no reason to treat their Arab neighbours any differently. The problem however in securitizing and generalizing ethnic minorities, in the case of France, the UK and Germany, is that a majority tend to end up living in isolation despising their fate and thus "provoking violent interaction between natives and the immigrant population" (Mantouvalou, 2005: 123). Religious profiling such as the already mentioned German system of spying on Islamic university students, the over-policing of specific community groups, or incrimination based on association are just some of the after shocks felt by national xenophobic laws. According to Statewatch more than 71,000 stop and searches were conducted in 2002-2003 as part of the anti-terrorist operations. In only $1.18 \%$ of cases, was an arrest made and a vast majority of which were not even connected to terrorism. In France, during recent years security measures have been tightened in the 'Islamic suburbs', effectively militarizing French housing estates - the latest internal security act has introduced a 2 year jail term for the new offence of loitering in stairwells or other communal areas of tower blocks (Fekete, 2004: 12).

Muslim migrants are locked in a cycle of discrimination, criminalization and stereotyping. As Tariq Ramadan put it in a recent interview with the radio show To the Best of Our Knowledge on Wisconsin Public Radio, the "issue is not a clash of civilizations, but a clash of perceptions" (March 25 $\left.5^{\text {th }}, 2007\right)$. 


\section{Present and Future Implications for the EU}

On the $13^{\text {th }}$ of February 2007, Dr. Hans-Gert Pöttering, President of the European Parliament, declared in his inaugural speech that, "Europe's future is dependant to a great extent on successful coexistence among cultures and religions within the European Union and between the European Union and our neighbours, first and foremost in the Arab and Islamic world" (Pöttering, 2007: 14). Based on truth and mutual tolerance, Pöttering suggested that the Euro-Mediterranean Assembly be used for dialogue with the Middle East, Israel and the rest of the Arab world. He is not alone in his desire to use existing institutions within the EU to improve relations between Europe and its migrant population. Benita Ferrero-Waldner, the EU Commissioner for External Relations and European Neighbourhood Policy (ENP), acknowledges the unique position the European Commission is in to foster better understanding between Europe and the Islamic world arguing that the through the ENP, the EU is "trying to manage migration better: welcoming those migrants we need for our economic and social well-being, while clamping down on illegal immigration" (FerreroWaldner, 2006: 141). Through the ENP, she argues, the EU will improve border controls, fight illegal immigration, and upgrade reception facilities for asylum traffic. Furthermore, ongoing bi-lateral negotiations with Algeria and Morocco (the most popular points of origin for French and Belgium Islamic migrants) in 2004 spoke of "installing high-tech equipment in neighbouring countries" to limit the number of illegal migrants crossing into the EU from Northern Africa (Johanson-Nogues, 2004: 246). Repeatedly what we are seeing from EU representatives is the framing of migration concerns as an issue of security that is apparently best addressed through 'hard' security measures. This is worrisome as immigrants, asylum seekers, and refugees are being framed as a security problem, reproducing the myth that a) a 
homogenous national community existed prior to 'their' entrance and b) that it can be reestablished today through the exclusion or control of migrants. By involving police, border guards, and intelligence services the EU and members of national governments are giving off the wrong message to their constituents and fellow Europeans. The way in which migration is rendered problematic, is the manner locals will view their migrant co-workers and neighbours:

How this dynamic [of migration] is portrayed in the media, discussed by political and cultural leaders, and managed by policy makers will determine whether the populations view increased diversity as a source of strength or as a threat (Alliance of Civilizations Report, 2006).

\section{Conclusion}

Late last summer former Foreign Secretary Jack Straw announced that he felt uncomfortable talking to his female Blackburn constituents face-to-face when they wore a full veil. He suggested that the conversation would have "greater value if the lady took the covering from her face". Almost immediately, Prime Minister Tony Blair and his heir apparent, Chancellor Gordon Brown, weighed in, giving their full support for Straw's comments arguing that, "a battle against the veil has been a long and continuing battle against the limitation of women" (Gomez, 2006). Statements such as these from Europe's political elite illustrate a serious misunderstanding when it comes to Islam and its traditions. Irrespective of one's point of view on the hijab question, what is most disconcerting to this author, is the choice of words Blair and Brown elect to use when referring to the head scarf debate; its seen as a 'battle' taking place between Islamic and Western religious traditions on British soil. Shore notes in his article "Can the West win Muslim Hearts and Minds?" that what "makes the head scarf so contentious is that people see in it what they want to see...ethnic Europeans tend to look upon the headscarf and see 9/11" (Shore, 2005: 484). For instance, in Germany, two opinion polls published by the Frankfurter Allgemeine Zeitung 
(FAZ) in late 2004 asked respondents what they associate "Islam" with and the most common responses were "suppression of women" (93 per cent) and "terror" (83 per cent) with only 6 per cent of respondents describing Islam as "likeable" (EUMC Report, 2006b: 37). Similar evidence can be found through out Europe in Spain, Italy, Denmark, the Netherlands, Austria, Sweden, and the United Kingdom.

This paper illustrates the power words and images are having on Europe's understanding of the world and the people that live within its borders. The media and political leaders must use their authority responsibly by accurately reporting events and resisting the temptation to sensationalize them. Standards have to be put in place to encourage a dialogue between ethnic, cultural, and religious groups to improve the quality of reporting, cognisant of the effect, "editorial decisions and opinions implicitly conveyed in reporting can have on the public's perception of an issue" (Alliance of Civilizations Report, 2006). Furthermore, politicians and the media should work together to help deepen inter-cultural understanding and resist the urge to legitimate racism by supporting the political platforms of the extreme right that propose hatred, discrimination, and intolerance (especially during times of external turmoil) purely for the sake of short-term electoral success. On the contrary, it is their duty as our elected representatives to reflect more profoundly the multicultural dynamics of European society and impede hateful expression not through increased government interference in the media but by encouraging the establishment of a voluntary code of ethics.

History has shown that laws such as the ATCSA do more harm than good: for example, following the Emergency Provisions Act of 1978, the Catholic community in Britain were left in widespread alienation and insecurity. However, Britons at large resisted the urge to blame or suspect everyone with an Irish accent. Similarly, it is worth noting that everything 
which is being said about the 'unsuitability of Muslims for life in a liberal democracy' was at one point said to the Catholic Irish who upon their arrival to the United States in the 1830s, had their religious allegiances questioned for they were assumed to be loyal to a "foreign potentate who deplored the liberalism and republican values" for which America had come to stand for (Legrain, 2006: 317). Ironic considering that US politicians like Pat Buchanan have since 9/11 have lathed on to popular misconceptions that 'Islamic immigrants are terrorists' so as to not only further their anti-immigrant agendas by exploiting their electorate's weaknesses and further feeding their fears about what a handful of them might do.

Over 170 years later not much has changed. The media, politicians, and laws continuto exploit the apprehension locals feel about what a handful of extremists might do, internalizing such a fear and voluntarily or involuntarily projecting such anxiety onto migrants and immigration in general. The worry here is that it might be too late. The securitization of migration is seeping into the policies and programs of the EU replicating the very cause it hopes to overcome. A better understanding of the implications of existing policies, laws and media practices is essential if the EU hopes to successfully deal with migration.

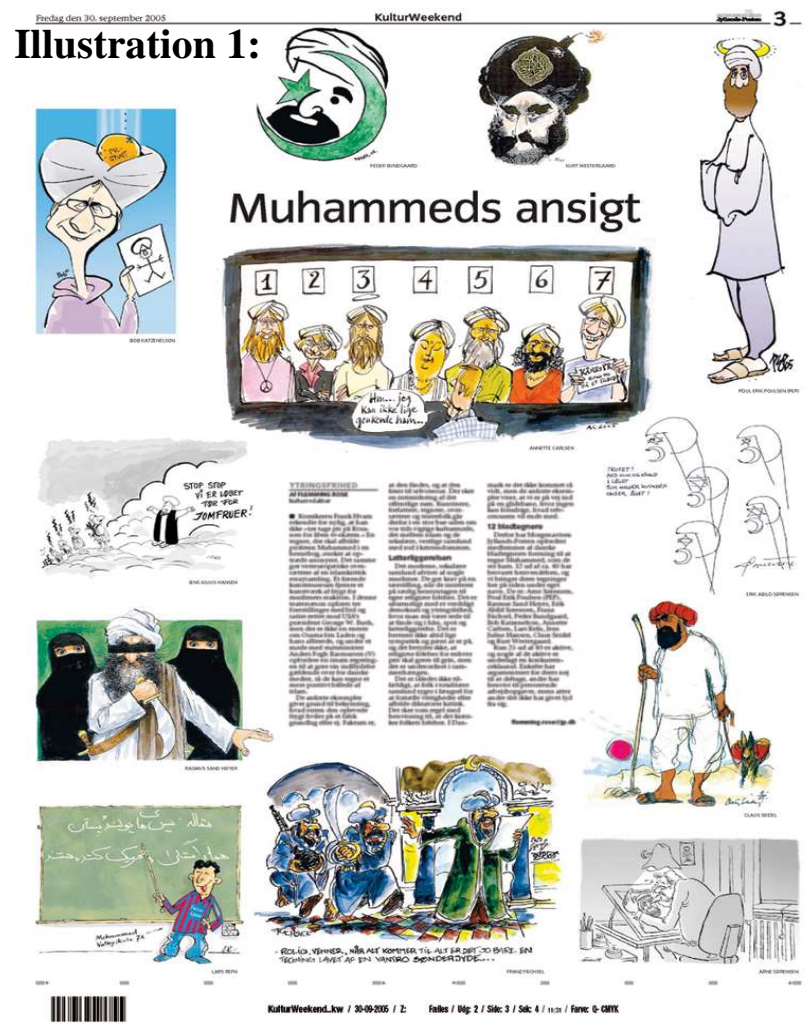




\section{Bibliography}

Abdullah Aslam. 2007. "Muslims and the Media since Post September 11", http://www.wkconline.org/resources/pdf/2005muslim_Aslam_Abdullah.pdf (September 2, 2007).

Bannerman, Patrick. 1988. Islam in Perspective. London: Routledge.

Barrenada, Isaías. 2006. "Alliance of Civilizations, Spanish Public Diplomacy and Cosmopolitan Proposal", Mediterranean Politics 11: 99-104.

Bollyn, Christopher. "Why the European Press is Provoking Muslims", http://www.rumormillnews.com/cgi-bin/archive.cgi?read=84976 (September 2, 2007)

The Economist. 2007. "Testing Muslim Views: If you want my Opinion”, Economist: 56-58, March 10.

European Commission 2006a. "Perceptions of Discrimination and Islamophobia: Voices from members of Muslim communities in the European Union", European Monitoring Centre on Racism and Xenophobia. http://eumc.europa.eu/eumc/material/pub/muslim/Perceptions_EN.pdf

2006b. "Muslims in the European Union: Discrimination and Islamophobia", European Monitoring Centre on Racism and Xenophobia, http://eumc.europa.eu/eumc/material/pub/muslim/Manifestations_EN.pdf

European Parliament, Press Release. 28 September 2006. "European Parliament sets out views on Immigration", http://www.europarl.europa.eu/news/expert/infopress_page/019-10973-26809-39-902-20060922IPR10897-25-09-2006-2006-false/default_en.htm (September 2, 2007).

Fekete, L. 2002a. "Centre-Right opens up aggressive debate about immigration and integration"'http://www.irr.org.uk/europebulletin/netherlands/immigration_law/2002/ak000 002.html (September 2, 2007) . 2002b. "Centre-Right attacks immigration and multiculturalism" http://www.irr.org.uk/europebulletin/spain/immigration_law/2002/ak000001.html (September 2, 2007) . 2004. "Anti-Muslim racism and the European security state", Race \& Class 46:1, 329.

Ferrero-Waldner, Benita. 2006. "The European Neighbourhood Policy: The EU's Newest Foreign Policy Instrument”, European Foreign Affairs Review 11: 139-142 
Gomez, E, "Britain's Straw lifts veil on Muslim-veil debate - and ignites firestorm”, SF Gate online article,http://www.sfgate.com/cgibin/blogs/sfgate/detail?blogid=15archive/\&entry_id= 9731

Henkel, Heiko. 2006. "The Journalists of Jullands-Posten are a bunch of reactionary provocateurs", Radical Philosophy 137: 2-7.

Johansson-Nogués, Elisabeth. 2004. "A Ring of Friends? The Implications of the European Neighbourhood Policy for the Mediterranean”, Mediterranean Politics 9: 240-247.

Kundnani, Arun. 2002. 'The death of multiculturalism', Institute of Race Relations http://www.irr.org.uk/2002/april/ak000001.html

Legrain, Phillip. 2006. Immigrants - Your Country Needs them. London: Little Brown Book Group.

Mantouvalou, Kiriaki. 2005 "Immigration as a Security Concern: The Case of Greece", Slovo 17: 119-136.

Papadimitriou, Demetrios. 2005. “Think Again: Migration”, Foreign Policy 109: 15-31

Pöttering, Hans-Gert. 2007. “Defending Europe's values - for a citizens' Europe Implementing reforms - for democracy and the parliamentary system Encouraging a dialogue of cultures - for partnership and tolerance." Strasbourg:

http://www.europarl.europa.eu/eplive/expert/multimedia/20070213MLT03070/media_200702 13MLT03070.pdf

Program on International Policy Attitudes. 2007. "Global Poll finds that Religion and Culture are Not to Blame for Tensions between Islam and the West", Washington D.C.: http://www.worldpublicopinion.org/pipa/articles/home_page/317.php?nid=\&id=\&pnt=317\&lb $=\mathrm{hmpg} 1$

Ramadan, Tariq. 2007. "To the Best of Our Knowledge", Radio interview with Ramadan, Tariq, March 25, 2007 on Wisconsin Public Radio: http://www.wpr.org/webcasting/ideas_audioarchives.cfm?Code=bok

Savage, Timothy. 2004. "Europe and Islam: Crescent Waxing, Cultures Clashing", Washington Quarterly 27: 25-50.

Shore, Zachary. 2005. "Can the West Win Muslim Hearts and Minds?” Orbis 5: 475-490.

United Nations. 2006. "Alliance of Civilizations Final Report". United Nations, http://www.unaoc.org/repository/report.htm (accessed September 2, 2007)

Walker, Martin. 2006. “Europe’s Mosque Hysteria”, Wilson Quarterly 30: 1-10. 
Zimmerman, Klaus. 1995. "Tackling the European Migration Problem." The Journal of Economic Perspectives 9: 45-62

Van Selm, Joanne. 2005. "Immigration is Becoming a Key Issue for Europe's Future", European Affairs 6: 1-3. 